\title{
Validation of Psychological Terminologies of Tridoshas and Trigunas
}

\author{
Shilpa Datar ${ }^{1}$, C. G. Venkatesha Murthy ${ }^{2}$
}

\section{ABSTRACT}

The authors have developed a set of scales to assess personality from the Indian psychological perspective of Tridoshas and Trigunas. This paper deals with psychological names to the Tridoshas and Trigunas as well as to the 16 Classical Personality types dealt in Ayurveda. The salient features of the Tridoshas, Trigunas and each of the 16 Classical Personality Types have been identified and validated which are elaborated.

Keywords: Personality assessment, 189 traits, 16 CPT, Sattva, Rajas, Tamas, Doshas and Gunas

Personality is basically understood by three major domains or methods in Indian Philosophy from which Indian Psychology has evolved. They are Pancha Kosha, Tridoshas and Trigunas. The Tridoshas and the Trigunas are both made up of the Pancha Mahabhutas in varying combinations and degrees.

The Pancha Mahabhutas form the most elemental composition of the universe. This is accepted in all the darsanas or schools of Indian philosophy. The Pancha Mahabhutas are elementary, found all over the world-albeit in varying combinations and degrees-and can form the basis for the proposition of personality understanding that is applicable to people across countries and socio-demographic situations to give us an understanding of people that is neither culturally specific nor constrained by geographical demarcations, giving us a psychology that is truly panglobal in nature (Shilpa \& Murthy, 2011a).

The authors have developed personality scales to assess Tridoshas i.e. Vata, Pitta and Kapha (Shilpa \& Murthy, 2011c) and Trigunas, i.e., Sattva, Rajas and Tamas (Shilpa \& Murthy, 2012a), from psychological perspective in human beings. The Tridoshas and Trigunas are composed of the Pancha Mahabhutas, but one or the other Dosha /Guna is dominant singularly or in combination. There can never be a state when one or the other Pancha Mahabhutas and consequently the Tridoshas and Trigunas are absent totally. All five are essential to sustain life. Though Tridosha and Triguna concepts are studied, understood and applied in Ayurveda, the present authors have validated the same from the domain of psychology.

\footnotetext{
1 “Sai Krupa”, 19/1, Bellary Road, Sadashivanagar, Bangalore—560 080; Karnataka, India

${ }^{2}$ Prof of Education, Regional Institute of Education, (NCERT), Mysore 570006; Karnataka, India *Corresponding Author

(C) 2015 I S Datar, C Murthy; licensee IJIP. This is an Open Access Research distributed under the terms of the Creative Commons Attribution License (http://creativecommons.org/licenses/by/2.0), which permits unrestricted use, distribution, and reproduction in any Medium, provided the original work is properly cited.
} 
The psychometric properties of one Tridosha as well as two Triguna scales have been established.

The Tridoshas form a bottom-up processing from the atomic and cellular level to give us an understanding of the person as a whole while the Trigunas form a top-down processing from the intellectual/ psychological level to give us an understanding of the person in totality. These two systems form the body-mind-spirit holistic unit of understanding personality that is very important and is a well-developed and tested methodology from Ayurvedic (principles)--(the medical aspect of Indian tradition) perspective, which has been handed down through the millennia, leading to a better understanding of human traits, types, behaviours, interests, attitudes, and natures. These two comprehensive methodologies of understanding people is panglobal and is applicable to people of all races, religions, ethnicities, genders, languages, cultures, geographical indicators and any and all divisions across the world and human civilization, without distinction. This respects that we are all a part of the same species while also allowing us unique personalities with different combinations of the same Pancha Mahabhutas.

Ayurveda talks about seven different combinations of doshas and gunas from the original three doshas (Tridoshas) and three gunas (Trigunas). All people are supposed to belong to one of these seven combinations of doshas, with a concurring combination of gunas leading to an interaction between the doshas and gunas leading to a unique personality development based on the dosha-guna combination-domination-suppression in every person.

\section{TRIDOSHAS AND THEIR BLENDS:}

Tridoshas refer to three doshas. Doshas refer to the state of physical-physiological combination. "Each dosha gives certain characteristic qualities to the person, based on which an individual can be classified as belonging to that particular dosha type. Charaka and Susruta recognize seven types or categories into which people can be classified, depending on the dominance of the doshas in their body. They are said to belong to a particular Prakriti or Constitution, as follows:

1. People with dominant Vata (constitution or) Prakriti.

2. People with dominant Pitta Prakriti.

3. $\quad$ People with dominant Kapha Prakriti.

4. People with dominant Vata-Pitta Prakriti.

5. People with dominant Vata-Kapha Prakriti.

6. People with dominant Pitta-Kapha Prakriti.

7. $\quad$ People with balanced doshas or with Vata-Pitta-Kapha Prakriti.

This is accepted by all the different schools of Ayurveda-Charaka, Susruta, Vagbhata, etc., to name a few (Sharma, 1981; Sharma, 2004; Murthy, 2007; Krishnan, 2002; Johari, 2003; and Svoboda, 2005)” (Shilpa \& Murthy, 2011a). 
"Proper balance between these three doshas is essential for good health. In a balanced state the doshas sustain the body by endowing good mental and physical strength to the individual. When they are in imbalance it leads to a dominance of one or more doshas (in combination), which is the cause of many ailments and illnesses” (Shilpa \& Murthy, 2011a, 2011b, 2012d, 2013a). "This also does not mean that a person who is either of the dosha dominated is not in good health. That particular dominant dosha is his natural state of being or Prakriti. It is not ill health” (Shilpa \& Murthy, 2011a, 2013a).

The Mysore Tridosha Scale has been standardized by the authors and the same has been published (Shilpa \& Murthy, 2011c). The traditional Ayurvedic names of Vata, Pitta and Kapha were imported into psychology and they were suitably described and named accordingly. The concordances of Ayurvedic experts were sought through their ratings on each of the names. The names were finalized accordingly. Their ratings and the finalized psychological names for Vata, Pitta and Kapha are given below.

Table 1: Psychological names and salient characteristics of Tridoshas

\begin{tabular}{|l|l|l|l|}
\hline $\begin{array}{l}\text { Sl. } \\
\text { No }\end{array}$ & Constructs & $\begin{array}{l}\text { Psychological } \\
\text { Names }\end{array}$ & Descriptions \\
\hline 1. & Vata & Impulsive & Unpredictable, erratic in all behaviour, fast, restless \\
\hline 2. & Pitta & Sharp & Short tempered, precise, sharp and decisive \\
\hline 3. & Kapha & Steadfast & $\begin{array}{l}\text { Stable, predictable, slow, dedicated and thorough in } \\
\text { all activities }\end{array}$ \\
\hline
\end{tabular}

The traditional Ayurvedic names of Vata, Pitta and Kapha were given psychological names and shown to experts. Their suggestions were incorporated and the psychological names were finalized accordingly. The finalized names are thus Impulsive for Vata, Sharp for Pitta and Steadfast for Kapha.

The salient characteristics for each of the three Doshas were also developed and shown to Ayurvedic experts. Consensus from them was obtained and the characteristics were finalized as mentioned in the table above.

Table 2: Ratings of eight Ayurvedic experts for psychological names to Tridoshas in percentages

\begin{tabular}{|l|l|l|l|l|l|l|}
\hline Construct & $\begin{array}{l}\text { Psychological } \\
\text { Names }\end{array}$ & $\begin{array}{l}\text { Highly } \\
\text { Agree }\end{array}$ & Agree & $\begin{array}{l}\text { Un- } \\
\text { decided }\end{array}$ & $\begin{array}{l}\text { Dis- } \\
\text { agree }\end{array}$ & $\begin{array}{l}\text { Highly } \\
\text { Disagree }\end{array}$ \\
\hline Vata & Impulsive & 37.5 & 62.5 & 0 & 0 & 0 \\
\hline Pitta & Sharp & 50 & 50 & 0 & 0 & 0 \\
\hline Kapha & Steadfast & 50 & 50 & 0 & 0 & 0 \\
\hline
\end{tabular}


An analysis of the above table indicates that the Ayurvedic experts have agreed to the psychological names given to traditional Ayurvedic names of Vata, Pitta and Kapha as above.

Thus, the above names are finalised by the authors based on the validation process.

\section{TRIGUNAS AND THEIR BLENDS:}

Trigunas refer to three gunas. Gunas refer to the quality and psychological states of the mind. "Each guna gives certain characteristic qualities to the person, based on which an individual can be classified as belonging to that particular guna type. Charaka and Susruta recognize seven types or categories into which people can be classified, depending on the dominance of the gunas in their body. They are said to belong to a particular guna combination, as follows:

1. People with dominant Sattva Guna.

2. $\quad$ People with dominant Rajas Guna.

3. People with dominant Tamas Guna.

4. People with dominant Sattva-Rajas Guna combination.

5. People with dominant Sattva-Tamas Guna combination.

6. $\quad$ People with dominant Rajas-Tamas Guna combination.

7. People with balanced gunas or with Sattva-Rajas-Tamas Guna combination.”

Shilpa \& Murthy (2011a) hold that there are many books and classical texts which have emulated references to these seven types of doshas and gunas (Charaka (Sharma 1981) and Susruta Samhitas (Murthy, 2001; Sharma 2004), Vagbhata's Ashtanga Hrdaya (Murthy, 1996) and Johari (2003), Svoboda (2005), Gupta (2000).

This seven-fold classification of people with respect to the gunas is similar to the seven-fold classification of people with respect to the dosha Prakriti. In fact it is identical in as much as one is concerned with the body constitution (Doshas = physical = Vata, Pitta and Kapha Prakriti) while the other is concerned with the mental or psychological characteristics exhibited by people (Gunas = psychological= Sattva, Rajas and Tamas gunas). Taking these two striking classifications one-step further, it would not be wrong to say that the physical constitution leads to the corresponding psychological attributes in a person or vice versa as both are inter dependant. Indian tradition does not share the Cartesian dichotomy of the body and the mind as is common in Western psychological thinking. In fact the interplay between the mind (Sattva), soul (Atman) and body (Sarira) in a tripod allusion is the corner stone of Ayruvedic Philosophy (Charaka Samhita, 46-47; Rao, 1990).

The Mysore Triguna Scale has been standardized by the authors and the same has been published (Shilpa \& Murthy, 2012a). The traditional names found in Ayurvedic as well as other classical Indian literature like the Bhagavad Gita, Upanishads, Yoga, Samkhya, etc., to name a few, for the Trigunas of Sattva, Rajas and Tamas were imported into psychology and they were suitably described and named accordingly. The concordances of Ayurvedic experts were sought through 
their ratings on each of the names. The names were finalized accordingly. Their ratings and the finalized psychological names for Sattva, Rajasand Tamas are given below.

Table 3: Psychological names and salient characteristics of Trigunas

\begin{tabular}{|l|l|l|l|}
\hline $\begin{array}{l}\text { Sl. } \\
\text { No. }\end{array}$ & Constructs & $\begin{array}{l}\text { Psychological } \\
\text { Names }\end{array}$ & Descriptions \\
\hline 1. & Sattva & Virtuous & Intelligent, fortitude, gentle, truthful, benevolent, virtuous \\
\hline 2. & Rajas & Alert & $\begin{array}{l}\text { Energy, harsh, angry, excessive activity, strong emotions, } \\
\text { inclining towards violence and aggression }\end{array}$ \\
\hline 3. & Tamas & Dormant & $\begin{array}{l}\text { Mass, heavy, obstructing, ignorance or lack of knowledge } \\
\text { (confused), inactivity, sleep (more), generally dejected } \\
\text { always, indecent }\end{array}$ \\
\hline
\end{tabular}

The traditional Indian names of Sattva, Rajas and Tamas were given psychological names and shown to eight experts. Their suggestions were incorporated and the psychological names were finalized accordingly. The finalized names are thus Virtuous for Sattva, Alert for Rajas and Dormant for Tamas. The salient characteristics of Sattva, Rajas and Tamas were identified and the same can be seen in the following table:

Table 4: Ratings of eight Ayurvedic experts for psychological names to Trigunas in percentages

\begin{tabular}{|l|l|l|l|l|l|l|l|}
\hline $\begin{array}{l}\text { SI } \\
\text { No }\end{array}$ & Construct & $\begin{array}{l}\text { Psychologica } \\
\text { I Names }\end{array}$ & $\begin{array}{l}\text { Highly } \\
\text { Agree }\end{array}$ & Agree & $\begin{array}{l}\text { Un- } \\
\text { decided }\end{array}$ & $\begin{array}{l}\text { Dis- } \\
\text { agree }\end{array}$ & $\begin{array}{l}\text { Highly } \\
\text { Disagree }\end{array}$ \\
\hline $\mathbf{1}$ & Sattva & Virtuous & 100 & 0 & 0 & 0 & 0 \\
\hline $\mathbf{2}$ & Rajas & Alert & 50 & 37.5 & 0 & 12.5 & 0 \\
\hline $\mathbf{3}$ & Tamas & Dormant & 50 & 37.5 & 0 & 12.5 & 0 \\
\hline
\end{tabular}

The above table indicates that the Ayurvedic experts have agreed to the psychological name Sattva fully, while for the other two constructs, Rajas and Tamas, a small percentage to the tune of $12.5 \%$ (one expert) has disagreed. Thus, a large majority of experts have agreed to the Psychological names given to Sattva, Rajas and Tamas. Thus, it is expected that these psychological names will help psychologists to study further and enhance the canvas.

\section{INTERRELATEDNESS OF TRIDOSHAS AND TRIGUNAS:}

Tridoshas are the physical components of the personality and the Trigunas are the psychological components of the personality. Both need to be studied and understood in tandem for a holistic understanding of personality. Negating the effect of either on the other is detrimental to the health and well-being of an individual. The present authors have studied the interrelationships of Tridoshas and the Trigunas in human personality empirically and established that the Tridoshas 
and the Trigunas interact with each other, which determine different aspects of an individual which are unique to that person (Shilpa \& Murthy, 2012b).

"Vata Dosha is a combination of Sattva and Rajas gunas, but is predominantly Rajasic. Pitta Dosha is a combination of Sattva, Rajas and Tamas gunas, but is predominantly Sattvic. Kapha Dosha is a combination of Sattva and Tamas gunas, but is predominantly Tamasic" (Shilpa \& Murthy, 2012d).

\section{The different types of Sattva, Rajas and Tamas personalities:}

Besides the basic three types of Dosha and three types of Guna leading to seven types of Tridosha characters and seven types of Triguna characters, "Ayurveda recognizes 16 types of personalities based on the classical guna theory. Both Charaka and Susruta Samhitas have a description of these types. According to them there are seven types of Sattva, six of Rajas and three of Tamas, totalling sixteen types of personalities under which all people can be grouped (Sharma, 1981; Sharma, 2004; and Murthy, 2007)” (Shilpa \& Murthy, 2012c). These are referred to as the 16 Classical Personality Types (16 CPT).

“The 16 Classical Personality types (16 CPT) are the manifestation of the amalgamation of VPK and SRT together. Hence the 16 CPT is expressed in terms of 16 independent personality types which are also expressed as different types of Sattva, Rajas and Tamas personalities in the classical literature. Therefore the subsequent analysis deals with SRT types which are essentially 16 CPT in nature. A list of all the traits which are characteristic of the 16 CPT (seven types of Sattva personalities, six types of Rajas personalities and three types of Tamas personalities) was drawn up” (Shilpa \& Murthy, 2014).

"There are 189 traits (common for both the physical and psychological aspects, hence there are 189 physical or VPK traits and 189 psychological or SRT traits) that have been identified which comprises the gamut of human behaviour. They are 100 Sattva traits, 60 Rajas traits and 29 Tamas traits..... Then these 189 traits are ..... combined in a set logic, wherein each trait is a characteristic behaviour exhibited by one (or more) of the 16 CPT as delineated in the classical texts.... So these 189 traits are all characteristics of these principal 16 CPT (these personalities too can be combined to give various combinations, to understand and classify people)" (Shilpa \& Murthy, 2013b). 
Table 5: Different types of Sattva, Rajas and Tamas

\begin{tabular}{|c|c|c|c|}
\hline Sl. No. & Types of Sattva & Types of Rajas & Types of Tamas \\
\hline 1. & Brahma Sattva & Asura Sattva, & Pasava Sattva \\
\hline 2. & Mahendra Sattva & Rakshasa Sattva & Matsya Sattva \\
\hline 3. & Varuna Sattva & Paisaca Sattva & Vanaspatya Sattva. \\
\hline 4. & Kubera Sattva & Sarpa Sattva & \\
\hline 5. & Gandharva Sattva & Praita Sattva & \\
\hline 6. & Yama Sattva & Sakuna Sattva. & \\
\hline 7. & Rishi Sattva. & & \\
\hline
\end{tabular}

The traditional names found in Ayurvedic as well as other classical Indian literature like the Bhagavad Gita, Upanishads, Yoga, Samkhya, etc., to name a few, for the 16 Classical Personality Typeswere imported into psychology and they were suitably described and named accordingly. The concordances of Ayurvedic experts were sought through their ratings on each of the names. The names were finalized accordingly. Their ratings and the finalized psychological names for the 16 Classical Personality Types are given below.

The salient characteristics of the 16 Classical Personality Types were identified and the same can be seen in the following table: (Shilpa \& Murthy, 2014)

Table 6: Psychological names and salient characteristics of 16 Classical Personality Types

\begin{tabular}{|l|l|l|l|}
\hline $\begin{array}{l}\text { Sl. } \\
\text { No. }\end{array}$ & Constructs & Salient Characteristics of 16 CPT & $\begin{array}{l}\text { Psychological } \\
\text { Names }\end{array}$ \\
\hline 1. & $\begin{array}{l}\text { Brahma } \\
\text { Sattva (S) }\end{array}$ & $\begin{array}{l}\text { Purity (in body, mind and speech); truthfulness; self- } \\
\text { control; discrimination; knowledge and wisdom; ability } \\
\text { to properly communicate; power of repartee; memory; } \\
\text { freedom from lust, anger, greed, arrogance, delusions, } \\
\text { envy, depression and intolerance; the tendency to be the } \\
\text { same with all beings; austerity; compassion; generosity } \\
\text { and virtue; piety; hospitality; reverence for teachers; and } \\
\text { inclination to the study of sacred texts. }\end{array}$ & $\begin{array}{l}\text { Selfous) } \\
\text { (Virtuous }\end{array}$ \\
\hline 2. & $\begin{array}{l}\text { Arsha Sattva } \\
\text { (S) }\end{array}$ & $\begin{array}{l}\text { Devoted to sacrificial ritual, study of the spiritual lore, } \\
\text { fulfilment of vows undertaken, chastity, and hospitality; } \\
\text { are free from pride, ego, attachment, aversion, confusion, } \\
\text { greed and anger; and are brilliant, eloquent, wise and } \\
\text { endowed with retentive memory; pure in body, speech } \\
\text { and mind; compassionate; given to repetition of sacred } \\
\text { formulae and study; celibacy; self-knowledge; and } \\
\text { wisdom. }\end{array}$ & $\begin{array}{l}\text { Mentor } \\
\text { (Virtuous) }\end{array}$ \\
\hline 3. & $\begin{array}{l}\text { Aindra Sattva } \\
\text { (S) }\end{array}$ & $\begin{array}{l}\text { Possessed of great power and their words are promptly } \\
\text { obeyed; they are often 'engaged in religious activities; } \\
\text { they are brave and strong, full of splendor; they refrain } \\
\text { from mean conduct; they are far-sighted and are devoted }\end{array}$ & $\begin{array}{l}\text { Ambitious } \\
\text { (Virtuous) }\end{array}$ \\
\hline
\end{tabular}




\begin{tabular}{|c|c|c|c|}
\hline & & $\begin{array}{l}\text { to virtuous living, wealth and pleasures of life; they are } \\
\text { learned and great; and they support good persons and } \\
\text { worthy causes; they are always engaged in studying the } \\
\text { scriptures and acting in accordance with them; they are } \\
\text { valorous and commanding; and they protect their } \\
\text { dependents. }\end{array}$ & \\
\hline 4. & $\begin{array}{l}\text { Yamya Sattva } \\
\text { (S) }\end{array}$ & $\begin{array}{l}\text { Preside over virtuous living and destiny. They have a } \\
\text { sense of propriety in their actions and a tendency to do } \\
\text { things in proper time; they are invincible and energetic; } \\
\text { they have strong memory, lust, envy, and anger; they are } \\
\text { prone to confusion; they are free from arrogance, fear } \\
\text { and anger; they are disposed favourably alike towards } \\
\text { friends and enemies; they are firm, active and pure in } \\
\text { their thoughts and actions. }\end{array}$ & $\begin{array}{l}\text { Objective } \\
\text { Decisive } \\
\text { (Virtuous) }\end{array}$ \\
\hline 5. & $\begin{array}{l}\text { Varuna } \\
\text { Sattva (S) }\end{array}$ & $\begin{array}{l}\text { Fond of water, love to sport in water-stretches, and feel } \\
\text { better in cold weather. They are generally clean and tidy; } \\
\text { and they love purity, and dislike dirt; they are } \\
\text { distinguished by valour, fortitude, love of rituals, and } \\
\text { hatred of mean conduct; they become indignant or } \\
\text { delighted as occasion demands; they think and act big, } \\
\text { engage themselves in virtuous conduct, and are quickto } \\
\text { get angry and also to relent; they are patient, love cold } \\
\text { things, have eyes with yellowish tinge and hair which is } \\
\text { reddish brown; they are soft-spoken and endear } \\
\text { themselves. }\end{array}$ & $\begin{array}{l}\text { Mature } \\
\text { Nourisher } \\
\text { (Virtuous) }\end{array}$ \\
\hline 6. & $\begin{array}{l}\text { Kaubera } \\
\text { Sattva (S) }\end{array}$ & $\begin{array}{l}\text { Pleasure-loving artistes, for they generally love wealth, } \\
\text { are fond of pleasures, inclined to live in comfort and } \\
\text { luxury, and prefer to have a large progeny. They are } \\
\text { usually surrounded by attendants, dependents, and } \\
\text { associates; they love prestigious positions and honour; } \\
\text { they engage themselves in virtuous conduct in amassing } \\
\text { wealth and satisfying their desires, but they prefer purity } \\
\text { of life; they are ready to reveal their pleasure and } \\
\text { displeasure; they crave possession of lands, houses, } \\
\text { engage servants, and are determined to be prosperous; } \\
\text { their indignation or their benevolence will not be in vain; } \\
\text { they are generally neutral in their attitude; they can endure } \\
\text { hardship while amassing wealth or while protecting it; and } \\
\text { are virile in progeny. }\end{array}$ & $\begin{array}{l}\text { Acquisitive } \\
\text { (Virtuous) }\end{array}$ \\
\hline 7. & $\begin{array}{l}\text { Gandharva } \\
\text { Sattva (S) }\end{array}$ & $\begin{array}{l}\text { Celebrated for their skill in singing, playing musical } \\
\text { instruments, and dancing. Persons belonging to this } \\
\text { variety have a lot of fondness for music and dance. They } \\
\text { delight in singing, dancing, and playing on instruments, } \\
\text { and they are proficient in musical discourses, recitation of } \\
\text { poems, narration of episodes and anecdotes .recounted in } \\
\text { mythical legends and epics; they love anointing } \\
\text { themselves with fragrant unguents, wearing fine dress; }\end{array}$ & $\begin{array}{l}\text { Romantic } \\
\text { (Virtuous) }\end{array}$ \\
\hline
\end{tabular}




\begin{tabular}{|c|c|c|c|}
\hline & & $\begin{array}{l}\text { and consorting with people from the opposite sex; they } \\
\text { are not jealous by temperament; they are comely to look } \\
\text { at, and are witty; they are fond of sporting. }\end{array}$ & \\
\hline 8. & $\begin{array}{l}\text { Asura Sattva } \\
(R)\end{array}$ & $\begin{array}{l}\text { Prevalence of evil inclinations, wicked thoughts, and } \\
\text { fierce temper, all of which characterize the evil spirits. } \\
\text { They delight in sensual pleasures. Persons answering to } \\
\text { this description are brave, fierce, and envious; they tend to } \\
\text { order people about and may assume terrifying aspects; } \\
\text { they are ruthless and conceited; they think ill even of good } \\
\text { people, and are fond of deceit; they alternate between } \\
\text { mercy and fear; they are quick to lose their temper, and } \\
\text { hate to find good qualities in others; they prefer to eat by } \\
\text { themselves, and love to move about under cover.Always } \\
\text { engaged in disturbing the sacrifices of noble people, are } \\
\text { gluttonous, destructive and impish. }\end{array}$ & $\begin{array}{l}\text { Dictatorial } \\
\text { (Alert) }\end{array}$ \\
\hline 9. & $\begin{array}{l}\text { Raksasa } \\
\text { Sattva (R) }\end{array}$ & $\begin{array}{l}\text { Intolerant, cruel, and constantly angry; they wait for } \\
\text { unguarded moments, or look for weak points, and strike; } \\
\text { they are gluttonous and relish meat for food; they are } \\
\text { also indolent and they sleep much; they are full of envy; } \\
\text { they are quarrelsome and revengeful; they are alien to } \\
\text { virtuous living, dogmatic in their views and full of self- } \\
\text { praise. }\end{array}$ & $\begin{array}{l}\text { Vengeful- } \\
\text { Warrior (Alert) }\end{array}$ \\
\hline 10. & $\begin{array}{l}\text { Paisaca } \\
\text { Sattva (R) }\end{array}$ & $\begin{array}{l}\text { Malignant, terrible and impish, they are ogres, and are } \\
\text { fond of eating flesh. Persons belonging to this variety are } \\
\text { not only unclean but delight in dirt; they are terrifying in } \\
\text { aspect but are timid and perplexed by nature; they love } \\
\text { perverted pleasures and obnoxious food; they love women } \\
\text { and seek to enjoy them in secret; they are extremely } \\
\text { indolent; they are cruel when not scared; they are } \\
\text { suspicious; they are gluttonous and especially fond of } \\
\text { meat and wine; they also relish left-overs; they are intense } \\
\text { in their anger, and at times become adventurous; they are } \\
\text { shameless. }\end{array}$ & Ogre (Alert) \\
\hline 11. & $\begin{array}{l}\text { Sarpa Sattva } \\
(R)\end{array}$ & $\begin{array}{l}\text { Quick temper, unforgiving and spiteful nature. Persons } \\
\text { belonging to this variety are constantly, quickly and } \\
\text { intensely roused (to wrath), but are timid when not } \\
\text { roused; they are quick to react and they strike hard; they } \\
\text { love food and sport, but are terrifying while they eat food } \\
\text { or while walking about; they spend much time in sleep, } \\
\text { but are very active while awake; they are vengeful and } \\
\text { their hatred is long-standing; they are full of deceit and } \\
\text { trickery. }\end{array}$ & $\begin{array}{l}\text { Revengeful } \\
\text { (Alert) }\end{array}$ \\
\hline 12. & $\begin{array}{l}\text { Praita Sattva } \\
(R)\end{array}$ & $\begin{array}{l}\text { Denote generally a disembodied spirit, seizing and } \\
\text { tormenting living beings. Their personality characteristics } \\
\text { are gluttonous, tortuous in their disposition and conduct, } \\
\text { envious, indiscriminate and impulsive, excessively } \\
\text { indulgent and inactive; they frequently experience }\end{array}$ & $\begin{array}{l}\text { Bully } \\
\text { (Alert) }\end{array}$ \\
\hline
\end{tabular}




\begin{tabular}{|c|c|c|c|}
\hline & & $\begin{array}{l}\text { dejection; they are miserly; they are conceited, hateful; } \\
\text { they are deformed in limbs and face; and they love } \\
\text { darkness (viz. night). }\end{array}$ & \\
\hline 13. & $\begin{array}{l}\text { Sakuna } \\
\text { Sattva (R) }\end{array}$ & $\begin{array}{l}\text { Have the traits peculiar to a predatory bird. Persons } \\
\text { belonging to this variety are passionately attached, are } \\
\text { excessively fond of food and roaming about, unsettled (in } \\
\text { place and, in thought), unforgiving and averse to gather } \\
\text { and store (non-acquisitive); they are intolerant, fond of } \\
\text { obnoxious food and vulgar speech; they are suspicious, } \\
\text { timid, and full of wicked thoughts; they incline } \\
\text { excessively to satisfy their own lust; and are constantly } \\
\text { eating. }\end{array}$ & $\begin{array}{l}\text { Emotionally } \\
\text { Unstable } \\
\text { (Alert) }\end{array}$ \\
\hline 14. & $\begin{array}{l}\text { Pasava Sattva } \\
\text { (T) }\end{array}$ & $\begin{array}{l}\text { These people are like dumb animals or beasts of burden, } \\
\text { which are guided solely by bodily urges and instincts. } \\
\text { Persons belonging to this variety are forbidding in their } \\
\text { disposition, despicable in their conduct, disgusting in their } \\
\text { food habits, sexy and given to excessive sleep; they have } \\
\text { little wit, and have no sense of cleanliness or refinement; } \\
\text { they are slow in their thoughts as well as their actions; } \\
\text { their preoccupation alternates between food and sex; and } \\
\text { they are generally negative in their attitude. }\end{array}$ & \begin{tabular}{|l} 
Bestial \\
(Dormant)
\end{tabular} \\
\hline 15. & $\begin{array}{l}\text { Matsya } \\
\text { Sattva (T) }\end{array}$ & $\begin{array}{l}\text { This group of people who are regarded as lower in the } \\
\text { level of life than the beasts of burden, for its physical and } \\
\text { psychological traits are extremely limited. Persons } \\
\text { belonging to this variety are timid, lacking in intelligence, } \\
\text { interested always in food, altogether unsettled (in place or } \\
\text { interest), passionately attached to desires and aversions, } \\
\text { fond of water, and given to constant mobility; they are } \\
\text { dull, gluttonous, uncontrollable in craving or in anger, } \\
\text { cruel, self-centred, and deceitful; they are virile and they } \\
\text { usually have a large progeny; they are foolish, and tend to } \\
\text { quarrel among themselves. }\end{array}$ & \begin{tabular}{|l} 
Boorish \\
(Dormant)
\end{tabular} \\
\hline 16. & $\begin{array}{l}\text { Vanaspatya } \\
\text { Sattva }(T)\end{array}$ & $\begin{array}{l}\text { These people signify a plant or tree, lower in the order of } \\
\text { life than even the fish. Persons belonging to this variety } \\
\text { are the least intelligent or active among all the varieties. } \\
\text { They are indolent, interested only in food, bereft of all } \\
\text { intelligence and discrimination; they are simpletons, } \\
\text { indifferent to cold, heat, wind, suffering and so on; and } \\
\text { are content to remain where they are placed. }\end{array}$ & $\begin{array}{l}\text { Apathetic } \\
\text { (Dormant) }\end{array}$ \\
\hline
\end{tabular}


Table 7: Ratings of eight Ayurvedic experts for psychological names to 16 Classical Personality Types

\begin{tabular}{|c|c|c|c|c|c|c|}
\hline Construct & $\begin{array}{l}\text { Highly } \\
\text { Agree }\end{array}$ & Agree & $\begin{array}{l}\text { Un- } \\
\text { decided }\end{array}$ & Disagree & $\begin{array}{l}\text { Highly } \\
\text { Disagre } \\
\text { e }\end{array}$ & $\begin{array}{l}\text { Psychologic } \\
\text { al Names }\end{array}$ \\
\hline $\begin{array}{l}\text { Brahma Sattva } \\
\text { (S) }\end{array}$ & 100 & 0 & 0 & 0 & 0 & $\begin{array}{l}\text { Self-realized } \\
\text { Ascetic }\end{array}$ \\
\hline Arsha Sattva (S) & 50 & 37.5 & 0 & 12.5 & 0 & Mentor \\
\hline $\begin{array}{l}\text { Aindra Sattva } \\
\text { (S) }\end{array}$ & 50 & 50 & 0 & 0 & 0 & $\begin{array}{l}\text { Ambitious } \\
\text { Leader }\end{array}$ \\
\hline $\begin{array}{l}\text { Yamya Sattva } \\
\text { (S) }\end{array}$ & 37.5 & 50 & 0 & 0 & 12.5 & $\begin{array}{l}\text { Objective } \\
\text { Decisive }\end{array}$ \\
\hline $\begin{array}{l}\text { Varuna Sattva } \\
\text { (S) }\end{array}$ & 50 & 25 & 0 & 25 & 0 & $\begin{array}{l}\text { Mature } \\
\text { Nourisher }\end{array}$ \\
\hline $\begin{array}{l}\text { Kaubera Sattva } \\
\text { (S) }\end{array}$ & 37.5 & 62.5 & 0 & 0 & 0 & Acquisitive \\
\hline $\begin{array}{l}\text { Gandharva } \\
\text { Sattva (S) }\end{array}$ & 50 & 50 & 0 & 0 & 0 & Romantic \\
\hline Asura Sattva (R) & 50 & 50 & 0 & 0 & 0 & Dictatorial \\
\hline $\begin{array}{l}\text { Raksasa Sattva } \\
\text { (R ) }\end{array}$ & 50 & 50 & 0 & 0 & 0 & $\begin{array}{l}\text { Vengeful- } \\
\text { Warrior }\end{array}$ \\
\hline $\begin{array}{l}\text { PaisacaSattva } \\
\text { (R ) }\end{array}$ & 50 & 37.5 & 12.5 & 0 & 0 & Ogre \\
\hline $\begin{array}{l}\text { Sarpa Sattva } \\
\text { (R) }\end{array}$ & 50 & 37.5 & 0 & 12.5 & 0 & Revengeful \\
\hline $\begin{array}{l}\text { Praita Sattva } \\
\text { (R ) }\end{array}$ & 37.5 & 62.5 & 0 & 0 & 0 & Bully \\
\hline $\begin{array}{l}\text { Sakuna Sattva } \\
\text { (R ) }\end{array}$ & 37.5 & 62.5 & 0 & 0 & 0 & $\begin{array}{l}\text { Emotionally } \\
\text { Unstable }\end{array}$ \\
\hline $\begin{array}{l}\text { Pasava Sattva } \\
\text { (T ) }\end{array}$ & 37.5 & 62.5 & 0 & 0 & 0 & Bestial \\
\hline $\begin{array}{l}\text { Matsya Sattva } \\
\text { (T ) }\end{array}$ & 37.5 & 50 & 0 & 12.5 & 0 & Boorish \\
\hline $\begin{array}{l}\text { Vanaspatya } \\
\text { Sattva (T) }\end{array}$ & 37.5 & 62.5 & 0 & 0 & 0 & Apathetic \\
\hline
\end{tabular}


The above table indicates that a large majority of Ayurvedic experts have agreed to the psychological names given to 16 Classical Personality Types. Thus, it is possible to give psychological names to the classical Ayurvedic names of the Tridoshas, Trigunas and the 16 CPT, the concepts of which have been taken from Ayurveda and validated in psychology. Thus these psychological names can be used in psychological studies.

\section{CONCLUSION:}

The traditional Ayurvedic/ Sanskrit names of Tridoshas and Trigunas as well as for the 16 Classical Personality Types are given psychological names and validated. This work is expected to take the studies in psychology forward in understanding and studying personality from Ayurvedic perspective.

\section{REFERENCES:}

Gupta, S. P. (2000). PSYCHOPATHOLOGY IN INDIAN MEDICINE. Delhi: Chaukhamba Sanskrit Prathishthan.

Johari, H. (2003). DHANWANTARI. New Delhi: Rupa and Co.

Krishnan, B. (2002). Typological conceptions in ancient Indian thought. In, Girishwar Misra \& Ajit K. Mohanty (Eds.). Perspectives on Indigenous Psychology. New Delhi: Concept Publishing Company. (Pages 292-304).

Murthy, K.R.S. (2007). (Translator). SUSRUTA SAMHITA. (1). Varanasi: Chaukhambha Orientalia.

Murthy, K.R.S. (1996). (Translator). VAGBHATA'S ASTANA HRDAYAM. (1). Varanasi: Krishnadas Academy.

Murthy, K.R.S. (2008). (Translator). BHAVAPRAKASA OF BHAVAMISRA. Varanasi: Chowkhamba Krishnadas Academy.

Murthy, P.H.C. (2007). (Translator). SARNGADHARA SAMHITA OF SARNGADHARACARYA. Varanasi: Chowkhamba Sanskrit Series Office.

Rao, S.K.R. (1990). (Ed.). MENTAL HEALTH IN AYURVEDA. (Source book of Charaka and Sushruta Samhita). Bangalore: NIMHANS.

Sharma, P. (1981). (Translator). CHARAKA SAMHITA. (1-4). Delhi: Chaukhambha Orientalia.

Sharma, P. (2004). (Translator). SUSRUTA SAMHITA. (1-3). Varanasi: Chaukhambha Visvabharati.

Shetty, M \& Babu, S. (2005). (Editors and Translators). YOGA RATNAKARA. Varanasi: Chowkhamba Sanskrit Series Office.

Shilpa S., \& Murthy, C.G.V. (Jan-March 2011a). Understanding Personality from Ayurvedic Perspective for psychological assessment: A Case. AYU-An International Quarterly Journal of Research in Ayurveda. 32, (1); pg. 12-19. (This paper was presented at National conference of Psychology held by NAOP and ICPR at IIT Guwahati in Dec. 2008). (ISSN: 0974-8520). http://www.ayujournal.org/text.asp?2011/32/1/12/85716 
Shilpa S., \& Murthy, C.G.V. (March 2011b). Conceptualizing Personality dynamics from the Indian thought. Indian Social and Psychological Studies (ISPS): 4, (1). pp. 6-19. (ISSN: 0974-634X)

Shilpa S., \& Murthy, C.G.V. (July-Sept. 2011c).Development and standardization of Mysore Tridosha Scale.AYU—An International Quarterly Journal of Research in Ayurveda; 32, (3). pg. 308-314. (ISSN: 0974-8520). DOI: 10.4103/0974-8520.93905 http://www.ayujournal.org/text.asp?2011/32/3/308/93905

Shilpa S., \& Murthy, C.G.V. (2012a). Development and standardization of Mysore Triguna Scale. Sage Open. Published 8 Feb. 2012. DOI: 10.1177/2158244012436564 http://sgo.sagepub.com/cgi/content/abstract/2158244012436564v1 and http://sgo.sagepub.com/content/early/2012/02/01/2158244012436564.full.pdf+html

Shilpa S., \& Murthy, C.G.V. (March, 2012b). Interrelatedness of Tridoshas and Trigunas in personality. An Empirical investigation. Indian Social and Psychological Studies (ISPS): 5, (1). pp: 32-40. (ISSN: 0974-634X).

Shilpa S., \& Murthy, C.G.V. (2012c). Combination of Trigunas in different groups of people. Journal of the Indian Academy of Applied Psychology.(Golden Jubilee Special Issue). 38, (3), pp: 214-219. (ISSN: 0019-4247).

Shilpa S., \& Murthy, C.G.V. (2012d). Understanding Personality dynamics from Ayurveda. Indian Journal of Health and Wellbeing. 3 (2), pp. 57-59.

Shilpa S., \& Murthy, C.G.V. (Jan 2013a). Combination of Tridoshas in different groups of people. Periyar University Journal of Psychology. 1 (1), p. 88-92.

Shilpa S., \& Murthy, C.G.V. (2013b). Development and standardization of Mysore Triguna Scale-Part B. Humanities and Social Science Studies. 2, (3), p. 82-97. ISSN: 2319829X.

Shilpa S., \& Murthy, C.G.V. (Jan. 2014). Assessment of traits and types in personality: An Indian psychological perspective. Indian Journal of Psychology. pp. 41-57. ISSN-00195553.

Svoboda, R.E. (2005). PRAKRITI. Delhi: Motilal Banarsidass Publishers Private Limited. 